\title{
Whole-Genome Expression Profiling of Bradyrhizobium japonicum in Response to Hydrogen Peroxide
}

\author{
Jeong-Min Jeon,, ${ }^{1,2}$ Hae-In Lee, ${ }^{1}$ Andrew J. Donati, ${ }^{1}$ Jae-Seong So, ${ }^{2}$ David W. Emerich, ${ }^{3}$ and \\ Woo-Suk Chang ${ }^{1}$ \\ ${ }^{1}$ Department of Biology, University of Texas-Arlington, Arlington 76019, U.S.A.; ${ }^{2}$ Department of Marine Science and \\ Biotechnology BK21 Program, Inha University, Incheon 402-751, South Korea; ${ }^{3}$ Department of Biochemistry, University \\ of Missouri, Columbia 65211, U.S.A.
}

Submitted 23 March 2011. Accepted 11 August 2011.

\begin{abstract}
Bradyrhizobium japonicum, a nitrogen-fixing bacterium in soil, establishes a symbiotic relationship with the leguminous soybean plant. Despite a mutualistic association between the two partners, the host plant produces an oxidative burst to protect itself from the invasion of rhizobial cells. We investigated the effects of $\mathrm{H}_{2} \mathrm{O}_{2}$-mediated oxidative stress on $\mathrm{B}$. japonicum gene expression in both prolonged exposure (PE) and fulminant shock (FS) conditions. In total, 439 and 650 genes were differentially expressed for the PE and FS conditions, respectively, at a twofold cut-off with $q<0.05$. A number of genes within the transport and binding proteins category were upregulated during $\mathrm{PE}$ and a majority of those genes are involved in $\mathrm{ABC}$ transporter systems. Many genes encoding $\sigma$ factors, global stress response proteins, the FixK transcription factor, and its regulatory targets were found to be upregulated in the FS condition. Surprisingly, catalase and peroxidase genes which are typically expressed in other bacteria under oxidative stress were not differentially expressed in either condition. The isocitrate lyase gene (aceA) was induced by fulminant $\mathrm{H}_{2} \mathrm{O}_{2}$ shock, as was evident at both the transcriptional and translational levels. Interestingly, there was no significant effect of $\mathrm{H}_{2} \mathrm{O}_{2}$ on exopolysaccharide production at the given experimental conditions.
\end{abstract}

Host plants can protect themselves from invasion of foreign microorganisms by using various defense mechanisms (Soto et al. 2006). A major defense mechanism is to produce an oxidative burst which represents an excessive amount of reactive oxygen species (ROS) (Iannelli et al. 1999). ROS, toxic derivatives of oxygen including superoxide anion $\left(\mathrm{O}_{2}^{-}\right)$, hydrogen peroxide $\left(\mathrm{H}_{2} \mathrm{O}_{2}\right)$, and hydroxyl radical $(\mathrm{OH} \bullet)$, can damage various cellular molecules including lipids, proteins, and DNA (Chang et al. 2006).

In the symbiotic association between legume plants and rhizobia, host plants also produce an oxidative burst during the infection process (Soto et al. 2006). Initially, the two partners exchange signaling molecules such as plant-derived isoflavonoids and the bacterium-derived Nod factors (Loh and Stacey 2001; van Rhijn et al. 1998). The initial signal exchanges acti-

Corresponding author: W.-S. Chang; E-mail: wschang@uta.edu; Telephone: +1.817 .272 .3280 ; Fax: +1.817.272.2855.

* The $e$-Xtra logo stands for "electronic extra" and indicates that three supplementary tables are published online. vate a series of events in the nodulation process, including root hair curling and infection, and, thereby, an intercellular tubelike structure called an infection thread is formed. Through the infection thread, rhizobia migrate toward the cortex. As rhizobia reach the cortex and proliferate, cortical cell division is initiated, eventually leading to the formation of root nodules where bacteroids, bacteria in the symbiotic state, reside to fix atmospheric nitrogen into ammonia (Dixon and Kahn 2004; Garg and Geetanjali 2009; Mylona et al. 1995; Pawlowski and Bisseling 1996). Among these events, the production of ROS is modulated at different time points and stages (Levine et al. 1994). Accumulation of $\mathrm{H}_{2} \mathrm{O}_{2}$ has also been observed in infection threads, but not detected in the nitrogen-fixing zone of the nodules (Rubio et al. 2004; Santos et al. 2001). In addition to intracellular ROS during symbiosis, free-living rhizobia in the rhizosphere might experience ROS constantly produced by plants due to aerobic metabolism during their development. However, the level of ROS could be lower compared with that produced as a consequence of defense mechanisms (Chang et al. 2009).

In order to initiate successful nodule formation in the Bradyrhizobium-soybean symbiosis, the rhizobial partner Bradyrhizobium japonicum must overcome the ROS-involved host defense mechanism and, thereby, adapt to a different level of oxidative stress. Several strategies by which bacteria cope with ROS include production of antioxidant molecules and ROSscavenging enzymes such as superoxide dismutase (SOD) and catalase (Barloy-Hubler et al. 2004; Santos et al. 2001). SOD detoxifies $\mathrm{O}_{2}{ }^{-}$and produces $\mathrm{H}_{2} \mathrm{O}_{2}$, which can be further detoxified by either catalase or peroxidase (Scandalios 1993). In addition, exopolysaccharides (EPS) have been demonstrated to build a protective slime layer in adverse environmental conditions (D'Haeze and Holsters 2004). For example, EPS-deficient mutants of the plant-pathogenic bacterium Pseudomonas syringae were more sensitive to ROS than the wild-type strain (Kiraly et al. 1997), indicating that an EPS matrix is able to protect bacteria from ROS. Furthermore, EPS production and biofilm formation have been known to play an important role in tolerance to other stresses such as osmotic stress, desiccation stress, and immune responses (Cytryn et al. 2007; D'Haeze et al. 2004; Soto et al. 2006).

The effect of $\mathrm{H}_{2} \mathrm{O}_{2}$ in most bacteria, specifically in rhizobia, has been studied using shock treatments with a high concentration of $\mathrm{H}_{2} \mathrm{O}_{2}$ (Barloy-Hubler et al. 2004; Mongkolsuk and Helmann 2002). Bacteria were grown until mid- to late exponential phase prior to $\mathrm{H}_{2} \mathrm{O}_{2}$ treatments (Barloy-Hubler et al. 
2004; Chang et al. 2006; Palma et al. 2004). After a short incubation period, cells were harvested for downstream assays such as gene expression and enzyme activities. Unlike shock experiments, there is little study about rhizobial responses to tolerable, low concentrations of $\mathrm{H}_{2} \mathrm{O}_{2}$ for a long period of time. It is likely that, in the soil and rhizosphere, lower levels of ROS are occasionally generated by plants and other soil bacteria via the partial reduction of oxygen to water during respiration or exposure to redox reactions with metals and other compounds (Panek and O'Brian 2004; Storz et al. 1990). Thus, free-living rhizobial cells likely experience fluctuations of ROS in their soil and rhizosphere habitats.

Here, we investigate how B. japonicum responds to $\mathrm{H}_{2} \mathrm{O}_{2-}$ mediated oxidative stress when exposed to a lower concentration of $\mathrm{H}_{2} \mathrm{O}_{2}$ for a relatively long incubation period. We employed microarray technology to reveal a comprehensive gene expression pattern in this condition. We have also examined the effect of $\mathrm{H}_{2} \mathrm{O}_{2}$ on the gene expression of $B$. japonicum under fulminant shock (FS), in which cells are exposed to high concentrations of $\mathrm{H}_{2} \mathrm{O}_{2}$ for a short time period. Our transcriptomics studies reveal that $B$. japonicum utilizes a different set of genes to deal with $\mathrm{H}_{2} \mathrm{O}_{2}$-mediated oxidative stress generated by shock treatment than those used during prolonged exposure (PE) to $\mathrm{H}_{2} \mathrm{O}_{2}$.

\section{RESULTS}

\section{Growth and survivability of $B$. japonicum in response to $\mathrm{H}_{2} \mathrm{O}_{2}$.}

In order to have a basic inference of the bacterial response to $\mathrm{H}_{2} \mathrm{O}_{2}$-mediated oxidative stress, the growth and survival of B. japonicum was monitored at various concentrations of $\mathrm{H}_{2} \mathrm{O}_{2}$. Two different treatments were compared: PE and FS. In the former, low-cell-density cultures were exposed to different $\mathrm{H}_{2} \mathrm{O}_{2}$ concentrations and the growth was monitored by measuring cell turbidity. There was no difference in the growth rate up to $150 \mu \mathrm{M}$, whereas no growth was observed in the culture exposed to $350 \mu \mathrm{M} \mathrm{H}_{2} \mathrm{O}_{2}$ (Fig. 1). Interestingly, the culture with $250 \mu \mathrm{M}$ was in an intermediate situation, exhibiting a slower growth rate compared with the control. Thus, we chose the condition of $250 \mu \mathrm{M}$ for a transcriptomic study of $B$. japonicum grown until mid-log phase.

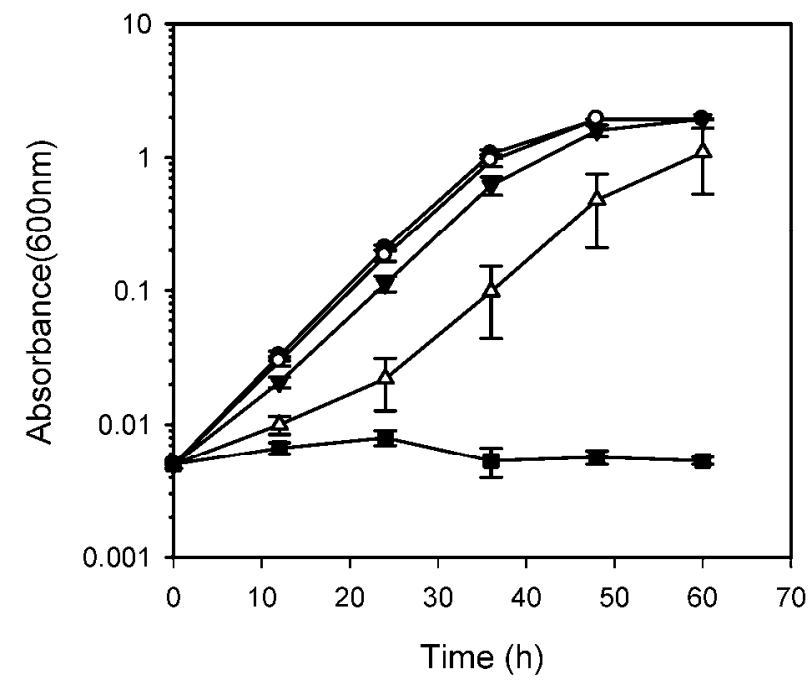

Fig. 1. Growth of Bradyrhizobium japonicum USDA110 treated with various concentrations of $\mathrm{H}_{2} \mathrm{O}_{2}$. Cell turbidity was measured and monitored at the optical density of $600 \mathrm{~nm}$. Each point is the mean of three biological replicates and the error bars represent the standard error of the mean. Symbols: ○, control; $\bigcirc, 75 \mu \mathrm{M} ; \nabla, 150 \mu \mathrm{M} ; \triangle, 250 \mu \mathrm{M} ; \mathbf{\square}, 350 \mu \mathrm{M}$.
The latter FS experiment was carried out to observe the detrimental effects of $\mathrm{H}_{2} \mathrm{O}_{2}$ at various concentrations and to determine a sublethal concentration of $\mathrm{H}_{2} \mathrm{O}_{2}$ for generating genomewide transcriptional profiles of $B$. japonicum. When cells were exposed to various concentrations of $\mathrm{H}_{2} \mathrm{O}_{2}$ for $2 \mathrm{~h}$, more than $60 \%$ survived at concentrations of up to $10 \mathrm{mM}$ (Fig. 2). However, the survivability significantly decreased within $10 \mathrm{~min}$ at concentrations higher than $20 \mathrm{mM} \mathrm{H}_{2} \mathrm{O}_{2}$. Our findings are consistent with an $\mathrm{H}_{2} \mathrm{O}_{2}$ challenge study on Sinorhizobium meliloti, where efficient detoxification occurs up to $10 \mathrm{mM}$ $\mathrm{H}_{2} \mathrm{O}_{2}$ and survival patterns are in a dose-dependent manner (Barloy-Hubler et al. 2004). For transcriptome analysis, we chose the condition of $10 \mathrm{mM} \mathrm{H} \mathrm{O}_{2}$ for $10 \mathrm{~min}$ of exposure due to its intermediate effects on cell survival.

\section{Genome-wide transcriptional profiles of $B$. japonicum} in response to $\mathrm{H}_{2} \mathrm{O}_{2}$-mediated oxidative stress.

To address the global gene expression changes of B. japonicum in response to $\mathrm{H}_{2} \mathrm{O}_{2}$-mediated oxidative stress, genomewide transcriptional profiles were generated from cells subjected to both PE and FS. In the former condition, RNA was isolated from cells grown to mid-log phase in the presence of $250 \mu \mathrm{M}$ $\mathrm{H}_{2} \mathrm{O}_{2}$ while, in the latter case, it was isolated from cells treated with $10 \mathrm{mM} \mathrm{H}_{2} \mathrm{O}_{2}$ for $10 \mathrm{~min}$.

Although the concentrations selected for the transcriptional analysis were based on growth or survival, we wondered whether $\mathrm{H}_{2} \mathrm{O}_{2}$ was still present in the culture at the time of cell harvest. There is considerable $\mathrm{H}_{2} \mathrm{O}_{2}(81 \mu \mathrm{M})$ remaining in the PE condition (Fig. 3A). We also measured endogenous $\mathrm{H}_{2} \mathrm{O}_{2}$ in the control culture (no $\mathrm{H}_{2} \mathrm{O}_{2}$ treatment) but were unable to detect it (data not shown), which rules out the possibility of remaining $\mathrm{H}_{2} \mathrm{O}_{2}$ coming from free-living cells in the culture medium. Surprisingly, in the $\mathrm{FS}$ condition, more than $95 \%$ of $\mathrm{H}_{2} \mathrm{O}_{2}$ was decomposed within $10 \mathrm{~min}$ (Fig. 3B), indicating that $\mathrm{H}_{2} \mathrm{O}_{2}$ detoxification may occur in a culture density-dependent manner.

In total, 439 genes were differentially expressed during PE at a twofold cut-off: 204 upregulated and 235 downregulated (Supplementary Table S1). Substantial numbers of downregulated genes were observed in the functional categories of

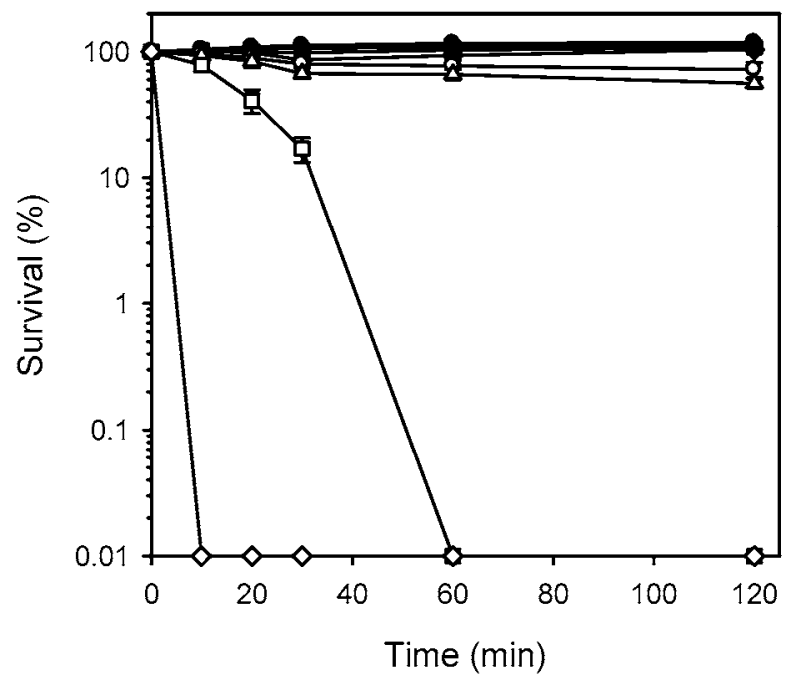

Fig. 2. Survival of Bradyrhizobium japonicum USDA110 after challenge with different concentrations of $\mathrm{H}_{2} \mathrm{O}_{2}$. Cells were grown in arabinose-gluconate media to an optical density at $600 \mathrm{~nm}$ of 0.8 . After exposure to $\mathrm{H}_{2} \mathrm{O}_{2}$ for a given time, cells were plated on agar medium and CFU were counted after 4 days of incubation at $30^{\circ} \mathrm{C}$. Each experimental data point is the average of three determinations. Error bars represent the standard error of the mean. Symbols: $\boldsymbol{\bullet}$, control; $\boldsymbol{\Delta}, 100 \mu \mathrm{M} ; \boldsymbol{\square}, 250 \mu \mathrm{M} ; \boldsymbol{\diamond}, 500$ $\mu \mathrm{M} ; \bigcirc, 1 \mathrm{mM} ; \triangle, 10 \mathrm{mM} ; \square, 20 \mathrm{mM}$;, $100 \mathrm{mM}$. 
amino acid biosynthesis, cellular processes, energy metabolism, and translation (Fig. 4). On the other hand, most of the differentially expressed genes within the transport and binding proteins category were upregulated. A majority of those genes are involved in $\mathrm{ABC}$ transporter systems, suggesting that extended exposure of B. japonicum to the low concentration of $\mathrm{H}_{2} \mathrm{O}_{2}$ induces ATP-dependent transporters with high substrate affinity.
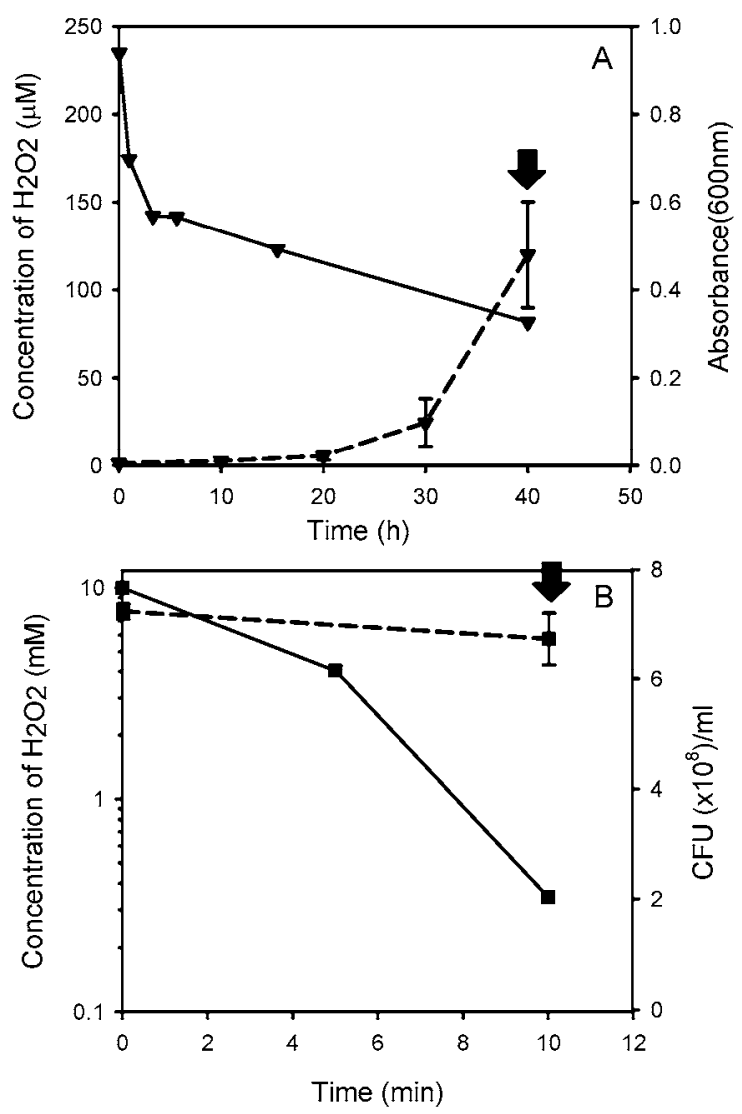

Fig. 3. Measurement of the remaining $\mathrm{H}_{2} \mathrm{O}_{2}$ concentrations during A, prolonged exposure and $\mathbf{B}$, fulminant shock. Solid lines indicate remaining $\mathrm{H}_{2} \mathrm{O}_{2}$ in the culture, and dashed lines indicate either $\mathbf{A}$, cell growth or $\mathbf{B}$, survival. Arrows indicate cell harvest time for RNA isolation.
In the FS condition, 650 genes were differentially expressed: 377 upregulated and 273 downregulated (Supplementary Table S2). Most of the induced genes belong to the functional categories of central intermediary metabolism, regulatory functions, and transport and binding proteins, whereas most of the downregulated genes are within energy metabolism and translation, with the exception of other categories and hypothetical categories (Fig. 4). The FS condition also induced many nitrogen fixation genes, including fix $K_{2}$ and its regulatory targets, particularly the fixNOQP and fixGHIS operons, excluding only fixH. These genes are known to be induced by the FixLJ-FixK ${ }_{2}$ regulatory pathway under micro-oxic conditions (Mesa et al. 2003; Nellen-Anthamatten et al. 1998). Of the 203 known targets of regulation for the fix $K_{2}$ transcription factor (Mesa et al. 2008), 79 genes (approximately 39\%) were induced in the FS condition. In addition, approximately $21 \%$ of the upregulated genes for the FS condition were part of the $\mathrm{FixK}_{2}$ regulon. Moreover, a fix $K_{2}$ mutant (B. japonicum 9043) was shown to have enhanced sensitivity to a $10-\mathrm{mM} \mathrm{H}_{2} \mathrm{O}_{2}$ shock treatment. After a 2-h challenge with $10 \mathrm{mM} \mathrm{H}_{2} \mathrm{O}_{2}$, the percent survival for the wild type was $56.0 \pm 4.78 \%$ whereas the fix $K_{2}$ mutant was $25.9 \pm 1.9 \%$. In addition, a filter disk assay revealed that the fix $K_{2}$ mutant was also more sensitive to $10 \mathrm{mM} \mathrm{H}_{2} \mathrm{O}_{2}$ than the wild type. The zone of inhibition for the mutant strain was $15.5 \pm 0.17 \mathrm{~mm}$ whereas that of the wild type was $11.8 \pm 0.44$ mm, with a $P$ value $<0.05$.

\section{Validation of microarray data by quantitative} reverse-transcription polymerase chain reaction.

We performed quantitative reverse-transcription polymerase chain reaction (qRT-PCR) to validate our microarray expression data. The expression of 21 genes (11 up- and 10 downregulated) that were selected based on expression values and functional categories was measured. The comparison of the expression values between the two different methodologies exhibited consistency and reproducibility (Fig. 5).

\section{Decreased ribosomal gene expression is evident in both PE and FS.}

The number of differentially expressed genes overlapping between both conditions is shown in a Venn diagram (Fig. 6). In all, 36 and 48 genes were commonly up- and downregulated for both conditions. Among these overlapping genes were 10 ribosomal protein-encoding genes commonly downregulated

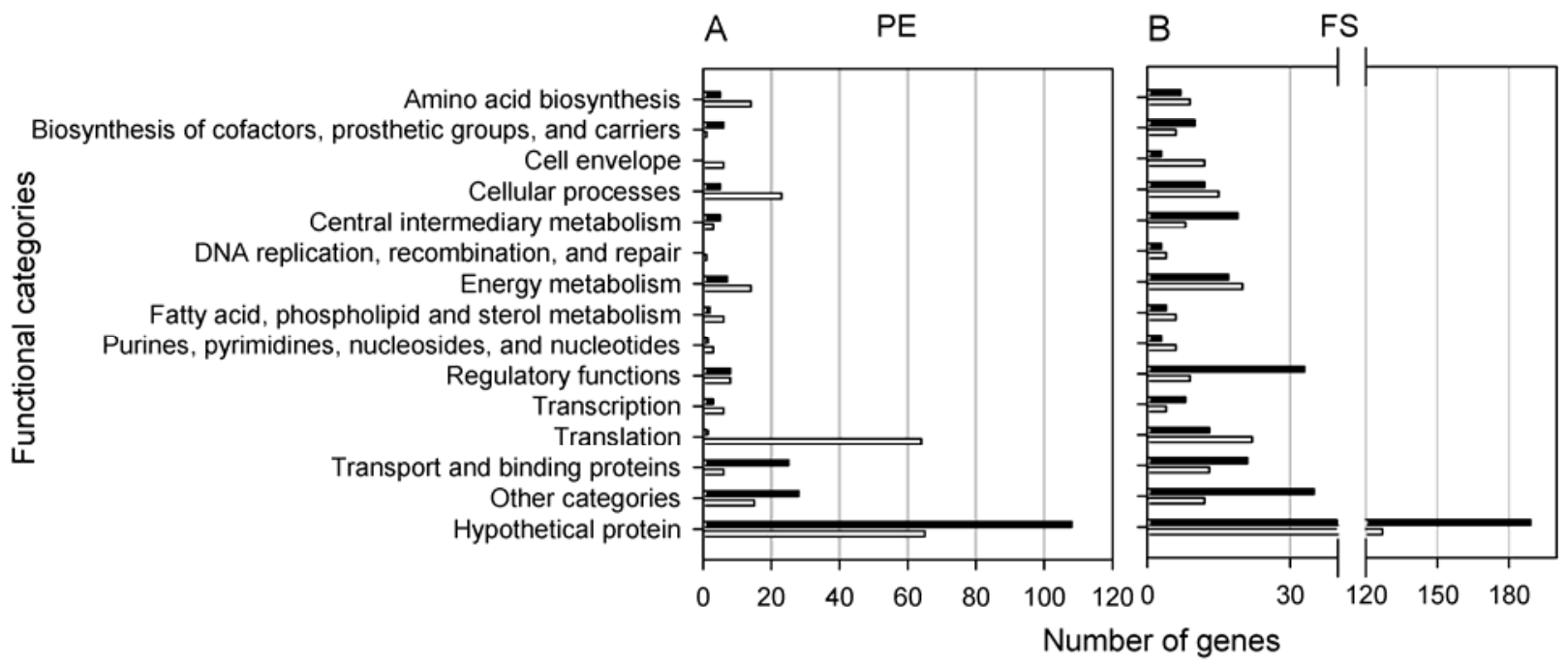

Fig. 4. Functional group assignments of genes differentially expressed in response to $\mathrm{H}_{2} \mathrm{O}_{2}$ in both prolonged exposure (PE) and fulminant shock (FS) at a 2.0 -fold cut-off with $q<0.05$. Black bars represent positive fold-induction values and white bars represent negative fold-induction values. Functional classifications were derived from Bradyrhizobium japonicum genome annotations available through Rhizobase. 
in both conditions (Table 1). In the PE condition, 64 translation genes, including all $30 \mathrm{~S}$ and $50 \mathrm{~S}$ ribosomal proteins (i.e., 54 genes), were downregulated and only 1 was upregulated. In the FS treatment, 22 translation-related genes, including the 10 overlapping ribosomal protein-encoding genes, were downregulated and 13 were upregulated. Interestingly, none of the upregulated genes encodes a ribosomal protein. This is in agreement with the previous transcriptome analysis of the Pseudomonas aeruginosa response to $\mathrm{H}_{2} \mathrm{O}_{2}$ (Palma et al. 2004). The expression of 41 of 54 ribosomal protein-encoding genes was downregulated in $P$. aeruginosa treated with $\mathrm{H}_{2} \mathrm{O}_{2}$.

\section{Differential expression}

of oxidative stress-responsive genes between PE and FS.

The FS treatment induced more stress-responsive genes, including chaperones and $\sigma$ factors, than the PE condition (Table 2), suggesting that fulminant $\mathrm{H}_{2} \mathrm{O}_{2}$ shock is a more severe stress to $B$. japonicum than prolonged incubation with the lower concentration of $\mathrm{H}_{2} \mathrm{O}_{2}$. The highest fold (107.8-fold) induction in the FS treatment is shown by bll1028 (carQ), which encodes a RNA polymerase $\sigma$ factor, indicating that $B$. japonicum might mainly utilize the $\sigma$ factor-related global stress response function to cope with $\mathrm{H}_{2} \mathrm{O}_{2}$-mediated fulminant oxidative stress. Heat and cold shock proteins and the GroEL chaperonin listed in Table 2 are other examples of global stress responses.

In total, 15 oxidative stress-responsive genes were induced in the FS treatment whereas only 4 genes were induced in the PE condition (Table 2). Among the responsive genes were two organic hydroperoxide resistance (ohr) genes (bll4012 and bl10735) which were highly upregulated (98.7- and 30.3-fold, respectively) in FS but not in the PE condition. Similarly, there was 4- to 10-fold induction of $o h r$ genes during $\mathrm{H}_{2} \mathrm{O}_{2}$ exposure in three $P$. aeruginosa strains (Salunkhe et al. 2005). Interestingly, many genes involved in an oxidoreductase function which catalyze electron transfer were upregulated in both PE and FS conditions, although one gene (bll0088) is downregulated in the FS treatment (Table 2). Unexpectedly, catalase (kat) and sod genes commonly known to be induced by oxida-

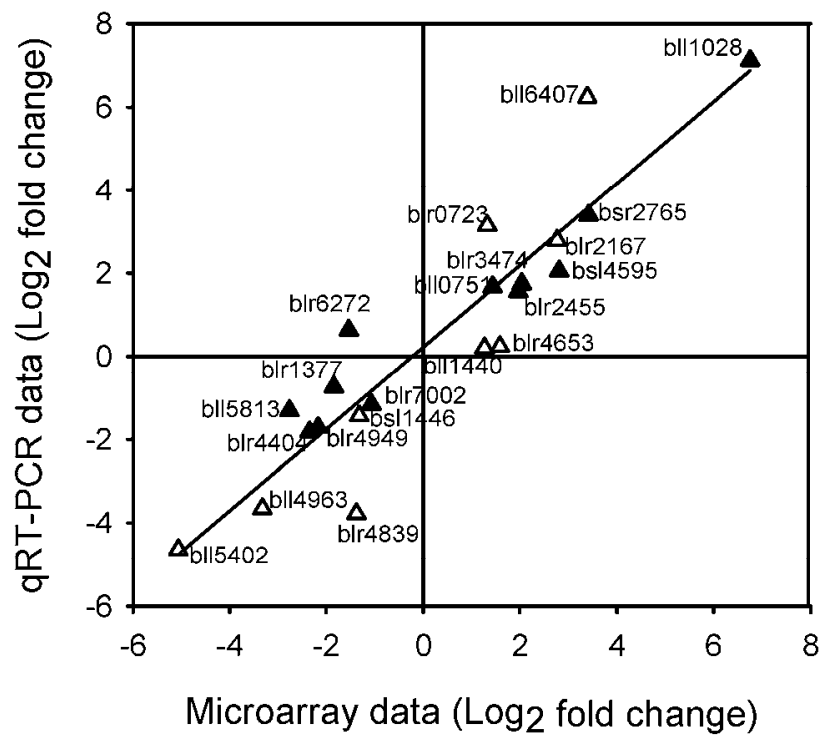

Fig. 5. Correlation between microarray and quantitative reverse-transcription polymerase chain reaction (qRT-PCR) data for both prolonged exposure (PE) and fulminant shock (FS) conditions for the selected genes (slope $=0.98, R^{2}=0.85$ ). These genes were chosen based on fold change and functional categories. Expression differences were $\log _{2}$ transformed. Symbols: $\triangle$, PE; $\boldsymbol{\Delta}$, FS. tive stresses were not differentially expressed in either condition. Because mRNA levels were measured at $10 \mathrm{~min}$ after treatment, we wondered if the expression of genes encoding canonical ROS detoxification enzymes occurs within 10 min. Thus, we employed qRT-PCR to check the expression of the following genes at 2 and 5 min after treatment with $10 \mathrm{mM}$ $\mathrm{H}_{2} \mathrm{O}_{2}$ : blr0778 (katG), blr5051 (sodM), bll7559 (Fe/Mn-sod), bll7774 (sodF), and bll0735 (ohr). All but bll0735 failed to meet 2.0-fold expression threshold values (data not shown). However, the ohr gene was induced 6- and 10-fold at 2 and 5 min, respectively. The possibility does exist that a longer exposure time could be effective in the induction of these genes.

\section{Isocitrate lyase activity is inducible by $\mathrm{H}_{2} \mathrm{O}_{2}$.}

Previously completed transcriptomic studies on several environmental conditions, such as desiccation stress (Cytryn et al. 2007), chemoautotrophy (Franck et al. 2008), and bacteroids (Chang et al. 2007a), have revealed strong induction of the isocitrate lyase gene (aceA). Interestingly, this gene was also upregulated by fulminant $\mathrm{H}_{2} \mathrm{O}_{2}$ shock. Isocitrate lyase functions in the glyoxylate bypass of the tricarboxylic acid (TCA) cycle by catalyzing the conversion of isocitrate into succinate and glyoxylate (Chell et al. 1978; Green et al. 1998). Previously, we constructed the isocitrate lyase (aceA; blr2455) mutant of B. japonicum (Franck et al. 2008), named WC2455. To restore the wild-type phenotype, its complemented strain, named WC2455-C, was constructed in this study.

The susceptibility of the WC2455 mutant to $10 \mathrm{mM} \mathrm{H}_{2} \mathrm{O}_{2}$ shock exposure is somewhat greater than the wild-type and WC2455-C strains (Fig. 7A), indicating that the lack of isocitrate lyase affects cell survival under $\mathrm{H}_{2} \mathrm{O}_{2}$-mediated oxidative stresses. The effects of $\mathrm{H}_{2} \mathrm{O}_{2}$ shock exposure on isocitrate lyase activity were also investigated across various time points up to $120 \mathrm{~min}$. The enzyme activity of the wild type dramatically increased at $20 \mathrm{~min}$ and stayed the same through $120 \mathrm{~min}$ (Fig. 7B). Given that the gene expression must occur before protein production, detection of the increased aceA mRNA at 10 min makes sense at both transcriptional and translational levels. In contrast, the mutant strain showed very little isocit-

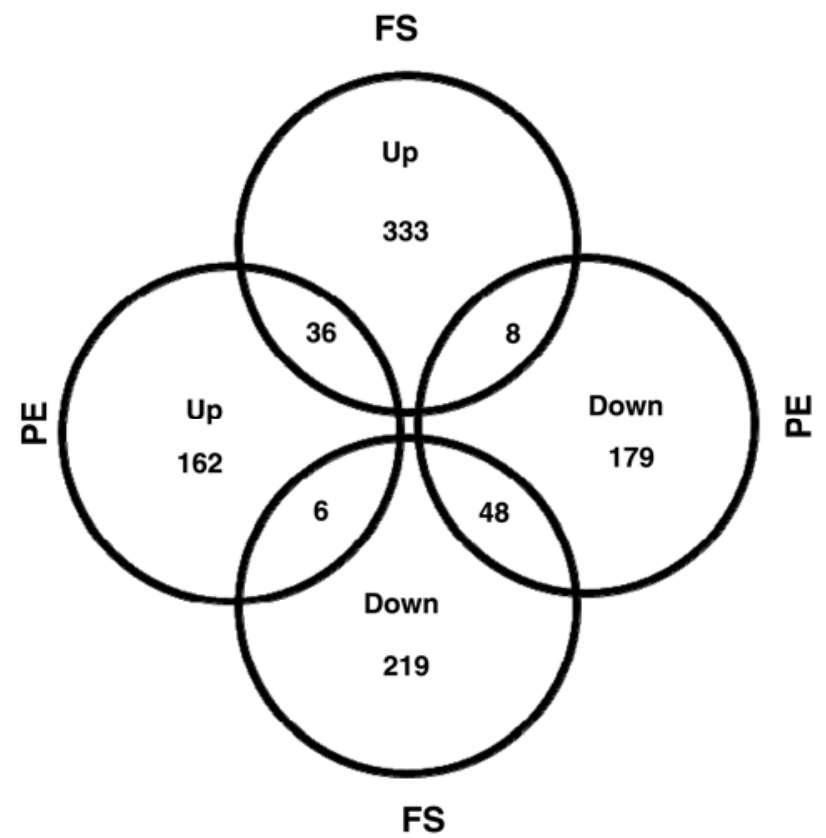

Fig. 6. Venn diagrams of the differentially regulated genes between prolonged exposure (PE) and fulminant shock (FS) conditions. Values shown represent more than twofold changes with $q<0.05$. 
rate lyase activity: $<1 \mathrm{U} / \mathrm{mg}$ and approximately $2 \mathrm{U} / \mathrm{mg}$ before and after $20 \mathrm{~min}$, respectively (Fig. 7B). Interestingly, the factor of induction is greater in the mutant strain when compared with the wild-type strain, even though the magnitude of the activity level is lower.

\section{EPS production is not induced by $\mathrm{H}_{2} \mathrm{O}_{2}$.}

We expected an induction of EPS biosynthesis-related genes during oxidative stress due to the protective nature of
EPS against ROS (Kiraly et al. 1997). However, our transcriptomic data do not support our expectation. Because there is a possibility of post-transcriptional modification on EPS biosynthesis pathways, we quantified the amount of EPS produced by $B$. japonicum exposed to various concentrations of $\mathrm{H}_{2} \mathrm{O}_{2}(75,150$, and $250 \mu \mathrm{M})$. Cells and supernatant were separated at mid- and late-log phases for EPS quantification. Contrary to our expectations, the total EPS amount was not significantly affected by these concentra-

Table 1. Partial list of genes commonly regulated during fulminant shock (FS) and prolonged exposure (PE) to $\mathrm{H}_{2} \mathrm{O}_{2}{ }^{\mathrm{a}}$

\begin{tabular}{|c|c|c|c|}
\hline \multirow[b]{2}{*}{ Locus (gene name) } & \multirow[b]{2}{*}{ Description $^{c}$} & \multicolumn{2}{|c|}{ Fold change $^{b}$} \\
\hline & & PE & FS \\
\hline bl11168 (tldD) & TldD protein & 2.0 & 2.7 \\
\hline blr1288 & Probable long-chain-fatty-acid-CoA ligase & 3.0 & 3.0 \\
\hline blr1309 (acs) & Acetyl-coenzyme A synthetase & 2.2 & 2.0 \\
\hline blr1404 (clpB) & ATP-dependent protease ATP-binding subunit & 2.4 & 2.4 \\
\hline bll2007 (hem N1) & Coproporphyrinogen III dehydrogenase & 2.6 & 2.2 \\
\hline bl12109 (fixK) & Transcriptional regulatory protein & 2.1 & 2.6 \\
\hline bl12542 (nadA) & Quinolinate synthetase A & 4.3 & 2.4 \\
\hline bsr2765 (fixQ) & cbb3 oxidase subunit IV & 2.4 & 10.7 \\
\hline blr2766 (fixP) & cbb3 oxidase subunit III & 2.1 & 6.3 \\
\hline bll3116 & Putative phosphoribosylpyrophosphate synthetase & 2.0 & 2.1 \\
\hline blr3179 & Probable alanine dehydrogenase oxidoreductase protein & 2.4 & 2.7 \\
\hline blr3214 (norC) & Nitric oxide reductase subunit $\mathrm{C}$ & 2.3 & 8.3 \\
\hline blr4112 & Probable cation efflux system protein & 2.5 & 4.2 \\
\hline blr4659 & PfkB family carbohydrate kinase & 2.7 & 3.1 \\
\hline bl16063 & $\mathrm{ABC}$ transporter substrate-binding protein & 2.2 & 2.2 \\
\hline blr6213 (mxaF) & Methanol dehydrogenase large subunit-like protein & 3.8 & 4.7 \\
\hline bll6220 & Putative alcohol dehydrogenase precursor & 5.9 & 2.3 \\
\hline blr7961 & Probable $\mathrm{HspC} 2$ heat shock protein & 3.3 & 2.1 \\
\hline bll7981 & Putative dehydrogenase & 2.2 & 7.3 \\
\hline bl17989 (mat) & $S$-adenosylmethionine synthetase & 2.2 & 2.0 \\
\hline blr0162 (rpmB) & 50S ribosomal protein L28 & -4.5 & -2.0 \\
\hline bl10439 (atpC) & ATP synthase $\varepsilon$ chain & -3.4 & -2.9 \\
\hline bll0441 (atpG) & ATP synthase $\gamma$ chain & -2.3 & -2.4 \\
\hline bl10442 (atpA) & ATP synthase $\alpha$ chain & -4.5 & -3.5 \\
\hline bl10456 (mdh) & Malate dehydrogenase & -2.4 & -2.1 \\
\hline blr0481 (ffh) & Signal recognition particle protein & -5.0 & -2.3 \\
\hline bl10504 (leuB) & 3-Isopropylmalate dehydrogenase & -2.3 & -2.3 \\
\hline bl10706 (pheS) & Phenylalanyl-tRNA synthetase $\alpha$ chain & -3.6 & -2.0 \\
\hline blr0745 (trpB) & Tryptophan synthase $\beta$ subunit & -2.0 & -2.1 \\
\hline bl11137 (cah) & Probable carbonic anhydrase & -2.5 & -2.5 \\
\hline blr1377 (etfS) & Electron transfer flavoprotein $\beta$ subunit & -2.8 & -3.6 \\
\hline bll1440 (ctpC) & Pilus assembly protein & -2.5 & -2.8 \\
\hline blr2025 (nodA) & Acyl transferase & -2.1 & -2.5 \\
\hline bs14078 (rpsR) & $30 \mathrm{~S}$ ribosomal protein $\mathrm{S} 18$ & -6.3 & -2.1 \\
\hline bsr4084 (acpP) & Acyl carrier protein & -2.4 & -2.0 \\
\hline blr4119 (ndk) & Nucleoside diphosphate kinase & -2.8 & -2.9 \\
\hline blr4340 & Probable ATP-binding protein & -2.9 & -2.2 \\
\hline bll4386 (efp) & Elongation factor $\mathrm{P}$ & -2.6 & -2.9 \\
\hline bll4734 (secF) & Protein-export membrane protein & -3.1 & -2.3 \\
\hline bl14736 & Preprotein tranlocase protein & -3.7 & -2.3 \\
\hline blr4838 ( $g l t \mathrm{X})$ & Glutamyl-tRNA synthetase & -2.1 & -2.5 \\
\hline bl14860 (tsf) & Translation elongation factor Ts & -2.6 & -2.0 \\
\hline blr4949 $(g \ln \mathrm{A})$ & Glutamine synthetase I & -2.4 & -4.5 \\
\hline bll4962 (rpsI) & $30 \mathrm{~S}$ ribosomal protein $\mathrm{S} 9$ & -3.4 & -2.2 \\
\hline bll5066 (rnpO) & RNA polymerase omega subunit & -3.2 & -2.2 \\
\hline bl15378 (rpsM) & 30 S ribosomal protein $\mathrm{S} 13$ & -3.7 & -2.2 \\
\hline bs15382 (rpmD) & $50 \mathrm{~S}$ ribosomal protein L30 & -16.7 & -2.1 \\
\hline bl15383 (rpsE) & 30s ribosomal protein S5 & -14.3 & -2.3 \\
\hline bll5403 (fus A) & Translation elongation factor $\mathrm{G}$ & -20.0 & -2.9 \\
\hline bl15404 (rpsG) & $30 \mathrm{~S}$ ribosomal protein $\mathrm{S} 7$ & -20.0 & -2.4 \\
\hline blr5706 (rpsD) & $30 \mathrm{~S}$ ribosomal protein $\mathrm{S} 4$ & -8.3 & -2.0 \\
\hline bll6497 (ilvC) & Ketol-acid reductoisomerase & -4.5 & -2.5 \\
\hline bll7440 (pth) & Peptidyl-tRNA hydrolase & -3.8 & -2.2 \\
\hline bll7441 (rplY) & 50S ribosomal protein L25 & -12.5 & -2.1 \\
\hline bs17548 (rpmJ) & 50S ribosomal protein $\mathrm{L} 36$ & -3.7 & -2.2 \\
\hline bsr8096 (rpmH) & Ribosomal protein L34 & -3.3 & -2.4 \\
\hline blr8101 (argB) & Acetylglutamate kinase & -2.1 & -2.4 \\
\hline
\end{tabular}

${ }^{\text {a }}$ Differentially expressed genes were selected based on a twofold cut-off with $q$ value $\leq 0.05$.

${ }^{\mathrm{b}}$ Positive and negative values indicate up and down regulation in response to $\mathrm{H}_{2} \mathrm{O}_{2}$, respectively.

${ }^{\mathrm{c}}$ Gene description (annotations) represents the third level from the three-tiered functional level system of B. japonicum. 
tions of $\mathrm{H}_{2} \mathrm{O}_{2}$ (data not shown), which is consistent with the transcriptomic data.

\section{DISCUSSION}

In this study, we observed differences in the expression profiles of $B$. japonicum in response to $\mathrm{H}_{2} \mathrm{O}_{2}$ stress in both $\mathrm{PE}$ and FS conditions. In cellular processes and energy metabolism, $\mathrm{H}_{2} \mathrm{O}_{2}$ appears to suppress aerobic respiration. Most of the respiration-related genes encoding ATP synthase subunits, the Rieske Fe-S protein/cytochrome $b c_{1}$ complex, and the cytochrome $a a_{3}$ terminal oxidase that are found in the electron transfer chain, were downregulated in both conditions. The $\alpha$ - and $\beta$-subunits of the $\mathrm{F}_{0} \mathrm{~F}_{1}$-ATPase are also reported to be specific proteins significantly damaged by oxidative stress (Zhang et al. 2008). Many genes encoding chaperones and several heat and cold shock protein families were upregulated by the fulminant $\mathrm{H}_{2} \mathrm{O}_{2}$ shock, whereas only one heat shock protein gene was upregulated in the PE condition (Tables 1 and 2). Specifically, probable HspC2 heat shock protein (blr7961) was upregulated in both conditions (Tables 1 and 2). Upregulation of these heat and cold shock proteins and molecular chaperones is known to play an important role for stress response defense mechanisms (Nollen and Morimoto 2002). Therefore, the induction of the heat and cold shock proteins during $\mathrm{H}_{2} \mathrm{O}_{2}$-mediated oxidative stress may serve to activate or enhance other bacterial stress response mechanisms.

The microarray data regarding the repression of genes encoding ribosomal proteins are consistent with slower growth and less survival data in the PE and FS conditions, respectively (Figs. 1 and 2), because, in general, faster growing cells highly express their ribosomal proteins and translation factors to make translational machinery available faster (Chang et al. 2007a; Tao et al. 1999). The canonical detoxification enzymes which are conventionally associated with a bacterial response to oxidative stress such as kat and sod genes were noticeably absent from the list of differentially expressed genes. A previous study with $P$. aeruginosa by Palma and associates (2004) revealed similar results, in that genes such as katE, katN, soxR, and $a h p B$ were not induced by the $\mathrm{H}_{2} \mathrm{O}_{2}$ treatment. This could be explained by the constitutive expression of those genes in

Table 2. List of chaperones, $\sigma$ factors, and oxidative stress-responsive genes differentially expressed in response to $\mathrm{H}_{2} \mathrm{O}_{2}{ }^{\mathrm{a}}$

\begin{tabular}{|c|c|c|c|c|}
\hline \multirow[b]{2}{*}{ Physiological process } & \multirow[b]{2}{*}{ Locus (gene name) } & \multirow[b]{2}{*}{ Description $^{c}$} & \multicolumn{2}{|c|}{ Fold change $^{b}$} \\
\hline & & & PE & FS \\
\hline \multirow[t]{14}{*}{ Chaperones } & bll0729 (hasp) & Small heat shock protein & $\ldots$ & 8.5 \\
\hline & blr7740 & Small heat shock protein & - & 8.0 \\
\hline & bs 14595 & Cold shock protein & - & 7.0 \\
\hline & blr4635 & Chaperonin GroEL & - & 3.4 \\
\hline & bsr3154 ( $\operatorname{csp} A)$ & Cold shock protein & - & 3.0 \\
\hline & blr2450 (htpx) & Protease heat shock protein & - & 2.6 \\
\hline & blr4637 & Probable HspC2 heat shock protein & - & 2.3 \\
\hline & blr1100 (hslO) & Heat shock protein 33 & - & 2.0 \\
\hline & blr7961 & Probable HspC2 heat shock protein & 3.3 & 2.1 \\
\hline & bll5834 (dksA) & dnaK deletion suppressor protein & - & -2.2 \\
\hline & blr4653 (dnaJ) & Molecular chaperone DnaJ family & 3.0 & - \\
\hline & bs13986 ( $\operatorname{csp} A)$ & Cold shock protein & -2.1 & - \\
\hline & blr5626 (groEL) & 60-kDa chaperonin & -2.3 & - \\
\hline & blr7533 (groEL) & $60-\mathrm{kDa}$ chaperonin & -3.3 & - \\
\hline \multirow[t]{5}{*}{$\sigma$ Factors } & bll1028 (carQ) & RNA polymerase $\sigma$ factor & - & 107.8 \\
\hline & blr7337 (rpoH2) & $\sigma 32$-like transcription factor & - & 5.9 \\
\hline & blr3038 (SigD) & Extracytoplasmic function family $\sigma$ factor & - & 5.0 \\
\hline & blr7797 & RNA polymerase $\sigma$-E factor $(\sigma-24)$ protein & 2.6 & -4.9 \\
\hline & blr1883 (rpoN1) & RNA polymerase $\sigma-54$ subunit & 2.3 & - \\
\hline \multirow[t]{24}{*}{ Oxidative stress response } & bll4012 (ohr) & Organic hydroperoxide resistance protein & - & 98.7 \\
\hline & bll0735 (ohr) & Organic hydroperoxide resistance protein & - & 30.3 \\
\hline & blr3215 (norB) & Nitric oxide reductase subunit $B$ & $\ldots$ & 12.1 \\
\hline & blr3214 (norC) & Nitric oxide reductase subunit $\mathrm{C}$ & $\ldots$ & 8.3 \\
\hline & bl13418 & Putative epoxide hydrolase 1 & - & 6.3 \\
\hline & bll7086 (hemN) & Anaerobic coproporphyrinogen III oxidase & - & 5.9 \\
\hline & bl17849 & Putative glutathione S-transferase & - & 5.1 \\
\hline & bsr0210 & Glutaredoxin & - & 3.6 \\
\hline & bll5249 & Oxidoreductase & - & 3.0 \\
\hline & bllo751 (trxA) & Thioredoxin C-1 & - & 2.7 \\
\hline & bll4149 & Putative glutathione peroxidase & - & 2.7 \\
\hline & bl16540 & Putative oxidoreductase & - & 2.4 \\
\hline & bll1295 & Probable oxidoreductase & - & 2.4 \\
\hline & bllo175 & Probable oxidoreductase & - & 2.1 \\
\hline & bll0593 & Putative oxidoreductase protein & - & 2.0 \\
\hline & blr1174 $(\operatorname{cox} G)$ & Putative cytochrome $\mathrm{C}$ oxidase assembly protein & - & -2.0 \\
\hline & blr2503 (gst) & Glutathione S-transferase & - & -2.1 \\
\hline & bl16732 & Probable glutathione peroxidase & - & -2.1 \\
\hline & blr1171 $(\operatorname{cox} A)$ & Cytochrome $\mathrm{C}$ oxidase subunit I & - & -2.3 \\
\hline & bllo088 & Oxidoreductase & - & -3.2 \\
\hline & blr2167 & Oxidoreductase & 6.8 & - \\
\hline & bl13376 & Putative oxidoreductase protein & 3.0 & - \\
\hline & blr5775 & Putative thioredoxin & 2.5 & - \\
\hline & blr6218 & Putative oxidoreductase protein & 2.4 & - \\
\hline
\end{tabular}

\footnotetext{
${ }^{\text {a }}$ Differentially expressed genes were selected based on a twofold cut-off with $q$ value $\leq 0.05$.

${ }^{\mathrm{b}}$ Positive and negative values indicate up- and downregulation, respectively, in response to $\mathrm{H}_{2} \mathrm{O}_{2}$; $-=$ not significantly expressed.

${ }^{\mathrm{c}}$ Gene description (annotations) represents the third level from the three-tiered functional level system of $\mathrm{B}$. japonicum.
} 
response to the endogenous production of $\mathrm{H}_{2} \mathrm{O}_{2}$ because control cells were growing aerobically.

Cells may also use alternative mechanisms such as the activation of various RNA polymerase $\sigma$ factors to reduce the toxicity of ROS. For example, bll1028 (carQ), blr7337 (rpoH2), blr3038 (sigD), blr7797, and blr1883 (rpoN1) were induced in either PE or FS, although blr7797 was repressed in FS (Table 2). Among them are $\operatorname{Car} Q$ and $\operatorname{Sig} D$, which are of particular interest because of their high gene expression and extracytoplasmic function (ECF). ECF $\sigma$ factors play essential roles in activating transcription of their regulons in adaptation to various environmental changes, including oxidative stress (Helmann 2002). Three ECF $\sigma$ factors have been known to play a role in response to oxidative stress. In Caulobacter crescentus, the ECF $\sigma$ factor $\sigma^{\mathrm{T}}$ is necessary for survival under oxidative stress (Alvarez-Martinez et al. 2007). Another example is Streptomyces coelicolor $\sigma^{\mathrm{R}}$ that modulates expression of the thioredoxin system in response to oxidative stress (Paget et al. 1998). The other ECF $\sigma$ factor, CarQ, found in Myxococcus xanthus, regulates biosynthesis of carotenoids, which are potent quenchers of singlet oxygen (Gorham et al. 1996).

$\mathrm{H}_{2} \mathrm{O}_{2}$-mediated oxidative stress also induced the FixK 2 transcription factor and its regulatory targets fixNOQP and fixGHIS in the FS condition. Fix $\mathrm{K}_{2}$ is known to control the fixNOQP operon, which encodes the high-affinity $c b b 3$-type terminal oxidase involved in bacteroid respiration under microaerobic and symbiotic conditions (Mesa et al. 2006, 2009). Other related genes involving the fixGHIS operon, the $\sigma$ factor $\left(r p o N_{1}\right)$, heme biosynthesis, and nitrate respiration are inducible under oxygen-limiting conditions (Fischer et al. 2001). However, Mesa and associates (2009) reported that oxidative stress repressed expression of these targets of the FixLJ-FixK ${ }_{2}$ regulatory pathways, which is inconsistent with our microarray data. These contradictory results may result from different background conditions. In this study, B. japonicum subjected to FS was grown under aerobic conditions, whereas cells were grown in a microaerobic condition in the previous study for the transcriptional analysis (Mesa et al. 2009), which makes it difficult to compare the two data sets. Another functional genomics study of the $B$. japonicum response to paraquat-mediated oxidative stress also revealed high expression of FixK $_{2}-$ related genes by fulminant paraquat shock (Donati et al. 2011), indicating that ROS may create a kind of the transitory microoxic condition inside the cells when they are aerobically cultivated.

Among the highly induced genes, blr2455 (aceA), which encodes isocitrate lyase, is a principal candidate for functional and physiological analyses because it is involved in the glyoxylate bypass of the TCA cycle and appears to play an important role in adaptation to various environmental stresses such as desiccation (Cytryn et al. 2007), chemoautotrophy (Franck et al. 2008), bacteroid differentiation (Chang et al. 2007a), and now $\mathrm{H}_{2} \mathrm{O}_{2}$-mediated oxidative stress. This gene is also induced by high salinity, acid shock stress, and low temperature in Colwellia maris, Mycobacterium tuberculosis, and Shewanella $\mathrm{sp}$. WP3, respectively (Fisher et al. 2002; Li et al. 2006; Watanabe et al. 2002). A previous study (Green et al. 1998) demonstrated that free-living $B$. japonicum possesses negligible isocitrate lyase activity. In that study, multiple carbon sources were compared. In this study, we confirmed the transcriptional data that show isocitrate lyase to be inducible in a condition of oxidative stress in addition to other stressful conditions. The results of the assay for isocitrate lyase activity also revealed low but detectable activity in the mutant strain even though this strain lacks a functional copy of the aceA gene. The measured activity cannot be from this protein because it is null. Therefore, we could speculate that isocitrate lyase activity in the aceA mutant is due to genetic heterogeneity, which implies that multiple genes contribute to the phenotype. Alternatively, the indirect enzyme assay that measures the accumulation of the phenylhydrazone derivative of glyoxylate could be a reason for a low level of the isocitrate lyase activity. The induction of aconitase (bll0466), citrate synthase (bll0182), and other pyruvate metabolism-related genes are also noteworthy to be addressed in that these genes link the TCA cycle and glycolytic pathway in $B$. japonocium. Similarly, in $P$. aeruginosa, genes whose products function in the TCA cycle and the terminal aerobic respiratory chain complex are upregulated in response to $\mathrm{H}_{2} \mathrm{O}_{2}$ (Salunkhe et al. 2005).

We also performed EPS quantification because our a priori hypothesis was that $B$. japonicum would produce more EPS as a defense mechanism against oxidative stress. However, our EPS quantification and transcriptomic data do not provide evidence to satisfy the hypothesis. Therefore, it may be possible that $\mathrm{H}_{2} \mathrm{O}_{2}$ could be too rapidly detoxified to have a significant effect on EPS production, or constitutive production of EPS could be sufficient to deal with a relatively low concentration of $\mathrm{H}_{2} \mathrm{O}_{2}$. In the latter case, $B$. japonicum cells may routinely produce EPS to protect themselves from endogenous ROS derived from the partial reduction of oxygen during aerobic respiration. In contrast, more EPS production has been detected by oxidative stress

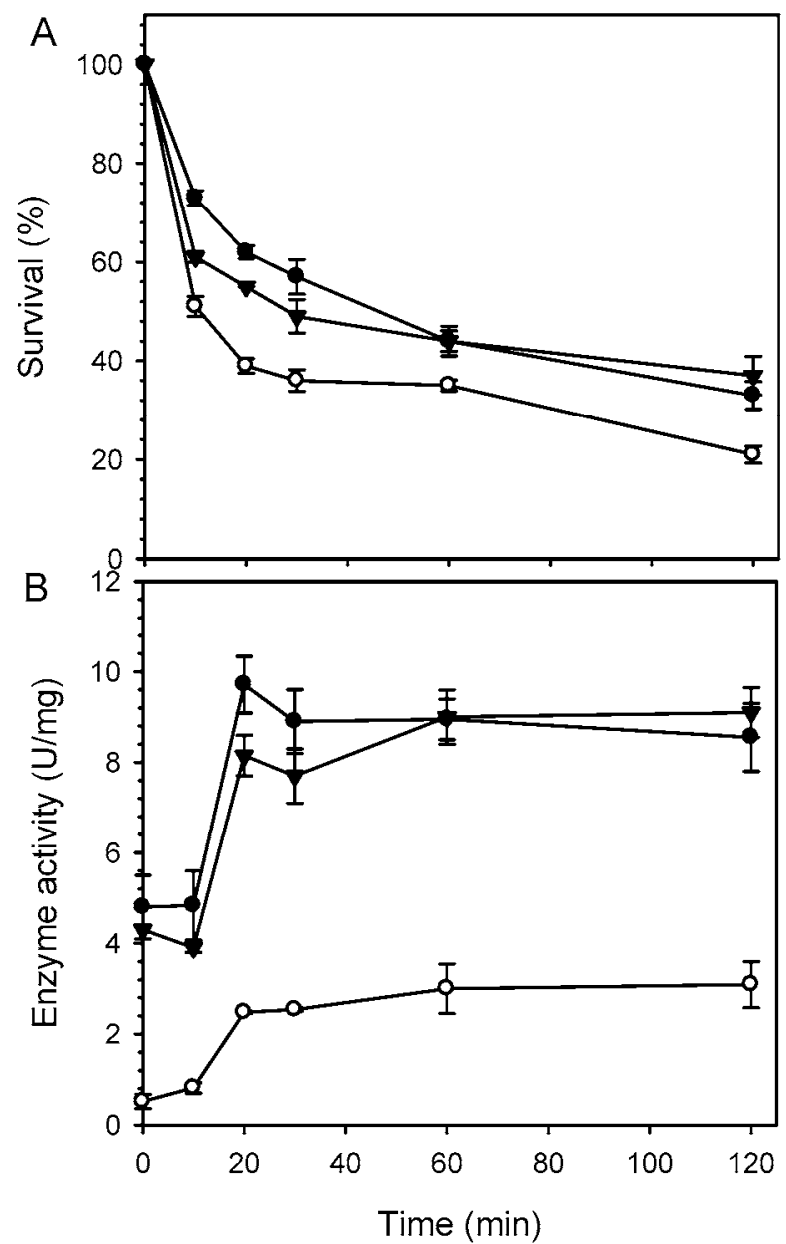

Fig. 7. Effect of $10 \mathrm{mM} \mathrm{H}_{2} \mathrm{O}_{2}$ shock on A, survival of the three Bradyrhizobium japonicum strains (wild type, WC2455, and WC2455-C) and B, their isocitrate lyase activities. Each experimental data point is the average of three determinations. One unit of isocitrate lyase activity is defined as the amount of enzyme required to produce $1 \mu \mathrm{mol}$ of glyoxylate per minute at $\mathrm{pH} 6.8$ and $30^{\circ} \mathrm{C}$. Symbols: - , wild type; O, WC2455; $\nabla$, WC2455-C. 
caused by paraquat, a known superoxide radical-inducing agent (Donati et al. 2011), indicating that superoxide radicals, rather than $\mathrm{H}_{2} \mathrm{O}_{2}$, are the primary ROS which can induce EPS biosynthesis of B. japonicum as a defense mechanism.

From the microarray data in this study and others, we speculate that most microorganisms may have overlapping and multiple pathways for detoxifying ROS. A number of bacteria that possess several defense mechanisms, including canonical detoxification enzymes, chaperones, and alternative $\sigma$ factors, differ in their temporal regulation in response to ROS (Mongkolsuk and Helmann 2002). Moreover, different forms of oxidative stresses and exposure times also disparately affect defense mechanisms. Thus, our findings may provide clues to the potential involvement of several listed $B$. japonicum genes whose mRNA expressions are modulated in response to $\mathrm{H}_{2} \mathrm{O}_{2}$, one of the ROS. Our continuing investigation will comprise of the mutagenesis of organic hydroperoxide resistance genes (bll0735 \& bll4012) and the ECF $\sigma$ factor (bll1028).

\section{MATERIALS AND METHODS}

\section{Bacterial strains and culture medium.}

B. japonicum USDA110 was inoculated at a concentration of $0.2 \%$ into $20 \mathrm{ml}$ of arabinose-gluconate (AG) medium (Sadowsky et al. 1987) and cultivated at $30^{\circ} \mathrm{C}$ with shaking at $200 \mathrm{rpm}$. AG media contain $125 \mathrm{mg}$ of $\mathrm{Na}_{2} \mathrm{HPO}_{4}$ (Fisher), 250 $\mathrm{mg}$ of $\mathrm{Na}_{2} \mathrm{SO}_{4}$ (Fisher Biotech, Fairlawn, NJ, U.S.A.), $320 \mathrm{mg}$ of $\mathrm{NH}_{4} \mathrm{Cl}$ (Fisher), $180 \mathrm{mg}$ of $\mathrm{MgSO}_{4} \cdot 7 \mathrm{H}_{2} \mathrm{O}$ (Sigma-Aldrich, St. Louis), $10 \mathrm{mg}$ of $\mathrm{CaCl}_{2}$ (Fisher), $4 \mathrm{mg}$ of $\mathrm{FeCl}_{3}$ (Fisher), $1.3 \mathrm{~g}$ of HEPES (Sigma-Aldrich), $1.1 \mathrm{~g}$ of MES (SigmaAldrich), $1.0 \mathrm{~g}$ of yeast extract (Difco Laboratories, Detroit), $1.0 \mathrm{~g}$ of L-arabinose (Sigma-Aldrich), and $1.0 \mathrm{~g}$ of D-gluconic acid sodium sulfate (Sigma-Aldrich) per liter. The fix $K_{2}$ mutant strain (B. japonicum 9043) was cultured in AG media supplemented with spectinomycin $\left(200 \mu \mathrm{g} \mathrm{m}^{-1}\right)$ and streptomycin $\left(100 \mu \mathrm{g} \mathrm{ml}^{-1}\right.$ ). The aceA mutant strain (B. japonicum WC2455) was cultured in AG media supplemented with kanamycin (150 $\mu \mathrm{g} \mathrm{ml} \mathrm{m}^{-1}$ ), and its complemented strain (WC2455-C) was cultured in the same medium supplemented with kanamycin (150 $\left.\mu \mathrm{g} \mathrm{ml}^{-1}\right)$ and tetracycline $\left(100 \mu \mathrm{g} \mathrm{ml}^{-1}\right)$.

\section{Experimental conditions for PE and FS.}

For $\mathrm{PE}$ to $\mathrm{H}_{2} \mathrm{O}_{2}$, a single colony was inoculated into $10 \mathrm{ml}$ of $\mathrm{AG}$, and broth cultures at $\log$ phase were inoculated at a concentration of $0.05 \%$ into $30 \mathrm{ml}$ of $\mathrm{AG}$ containing either $\mathrm{H}_{2} \mathrm{O}_{2}$ or the same volume of sterilized double-distilled (dd) $\mathrm{H}_{2} \mathrm{O}$ and incubated at $30^{\circ} \mathrm{C}$ with shaking at $200 \mathrm{rpm}$. These cultures were exposed to different concentrations of $\mathrm{H}_{2} \mathrm{O}_{2}$ (from 0 to $350 \mu \mathrm{M})$ for 2 days, and the optical density at $600 \mathrm{~nm}\left(\mathrm{OD}_{600}\right)$ was measured to determine growth rate and cell harvest time for RNA isolation. For the FS treatment, the 300-ml culture was cultivated until an $\mathrm{OD}_{600}$ of 0.8 , which gives approximately $1 \times 10^{9} \mathrm{CFU} / \mathrm{ml}$. Then, the culture was divided into eight $30-\mathrm{ml}$ cultures by pipetting into $125-\mathrm{ml}$ flasks and each culture was treated with various concentrations of $\mathrm{H}_{2} \mathrm{O}_{2}$ ranging from $100 \mu \mathrm{M}$ to $100 \mathrm{mM}$. Survival was monitored at 10 , 20, 30, 60, and $120 \mathrm{~min}$ after treatment. The control culture was supplemented with the same volume of sterilized $\mathrm{ddH}_{2} \mathrm{O}$. After exposure to $\mathrm{H}_{2} \mathrm{O}_{2}$, cells were washed with buffer and spread on AG agar plates. CFU were counted after 4 days of incubation at $30^{\circ} \mathrm{C}$. The same protocol was used to determine the percent survival for B. japonicum 9043 under the same experimental conditions for the wild-type strain.

\section{Filter disk assay.}

A comparison of the sensitivity of B. japonicum 9043 to 10 $\mathrm{mM} \mathrm{H}_{2} \mathrm{O}_{2}$ was also compared with the wild-type strain by means of a filter disk assay. Starter cultures for each strain were grown to an $\mathrm{OD}_{600}$ of 1.0 and reinoculated to an $\mathrm{OD}_{600}$ of 0.05 in $0.9 \%$ soft AG agar. A 6-mm filter disk (Becton Dickinson and Co., Franklin Lakes, NJ, U.S.A.) was soaked in 10 $\mathrm{mM} \mathrm{H} \mathrm{H}_{2} \mathrm{O}_{2}$ and placed at the top of each plate. A disk soaked in $\mathrm{ddH}_{2} \mathrm{O}$ was applied to the bottom of each plate to serve as a control. In total, three replications were performed for each strain. Zones of inhibition were measured in millimeters after a 4-day incubation period at $30^{\circ} \mathrm{C}$.

\section{Measurement of $\mathrm{H}_{2} \mathrm{O}_{2}$ in vitro.}

The scavenging of $\mathrm{H}_{2} \mathrm{O}_{2}$ by cells was examined as previously described (Panek and O'Brian 2004) and analysis was completed according to recommendation of the manufacturer's protocol using HRP reagent (Sigma-Aldrich) and Amplex Red reagent (10-acetyl-3,7-dihydroxyphenoxazine; Molecular Probes, Eugene, OR, U.S.A.). Aerobically grown cells were harvested at various time points when subjected to $250 \mu \mathrm{M} \mathrm{H}_{2} \mathrm{O}_{2}$ (for the $\mathrm{PE}$ condition) and $10 \mathrm{mM}$ (for the FS treatment). Cells were washed twice in $50 \mathrm{mM} \mathrm{NaPO}$ buffer ( $\mathrm{pH} \mathrm{7.0)}$ and resuspended in the same buffer. After incubation at $30^{\circ} \mathrm{C}$, aliquots were assayed immediately for remaining $\mathrm{H}_{2} \mathrm{O}_{2}$. The culture itself without $\mathrm{H}_{2} \mathrm{O}_{2}$ treatment was used as a control to check for endogenous $\mathrm{H}_{2} \mathrm{O}_{2}$ production by $B$. japonicum.

\section{Construction of an ace $A$-complemented strain.}

The $B$. japonicum aceA gene (blr2455) was amplified by PCR using the following primers: BamHICATGTTCTGATGT TAC and BamHITTCCGCCGTTAGCCGA, forward and reverse respectively. The amplified aceA gene was inserted in pGEM-T easy vector (Promega Corp., Madison, WI, U.S.A.). The 1.5-kb fragment of the BamHI-digested aceA gene and the BamHI-digested pTE3 (Egelhoff and Long 1985) expression vector (tetracycline resistant) were ligated to construct a 21.8$\mathrm{kb}$ recombinant plasmid. The resulting construct was transferred from Escherichia coli to the mutant strain WC2455 (Franck et al. 2008) by triparental mating with the helper strain pRK2073. Transconjugants were selected for kanamycin and tetracycline resistance. The complemented strain, named WC2455-C, possessing the recombinant plasmid was confirmed by colony PCR (data not shown).

\section{Isocitrate lyase enzyme assay.}

Cells grown in AG medium were harvested by centrifugation at $8,000 \times g$ for $5 \mathrm{~min}$ at $4{ }^{\circ} \mathrm{C}$. To remove the medium components, the cell pellets were washed once in $1 \mathrm{ml}$ of 50mM Tris-sodium EDTA (TNE) buffer (pH 7.0) and resuspended in $1 \mathrm{ml}$ of breaking buffer $(20 \mathrm{mM}$ TNE buffer [pH7.0], $100 \mathrm{mM} \mathrm{NaCl}, 5 \mathrm{mM} \mathrm{MgCl}{ }_{2}, 0.4 \mathrm{mM}$ EDTA, 1.5 $\mathrm{mM}$ dithiothreitol and $2 \%$ [wt/vol] glycerol) (Green et al. 1998). The suspension was subsequently homogenized by sonication for $1 \mathrm{~min}$ and the cell pellet was removed by centrifugation at $8,000 \times g$ for $5 \mathrm{~min}$.

The isocitrate lyase assay was performed according to recommendation of Sigma-Aldrich's protocol and the method of Chell, with some modifications (Chell et al. 1978). The reaction solution contained $30 \mathrm{mM}$ imidazole buffer ( $\mathrm{pH}$ 6.8), $5 \mathrm{mM} \mathrm{MgCl}$, $1 \mathrm{mM}$ EDTA, $4 \mathrm{mM}$ phenylydrazine hydrochloride (SigmaAldrich), and $1 \mathrm{mM}$ DL-isocitric acid (Sigma-Aldrich). To initiate the enzyme reaction, $0.1 \mathrm{ml}$ of freshly prepared cell-free extract was added to reaction mixture and incubated for $5 \mathrm{~min}$ at $30^{\circ} \mathrm{C}$. After incubation, the absorbance at $340 \mathrm{~nm}$ was measured to determine the enzyme activity. One unit of the isocitrate lyase activity was defined as the amount of substrate consumed to produce $1 \mu \mathrm{mol}$ of glyoxylate per minute at $\mathrm{pH} 6.8$ and $30^{\circ} \mathrm{C}$. The effect of fulminant $\mathrm{H}_{2} \mathrm{O}_{2}$ shock on the isocitrate lyase activity was determined at various time points up to $120 \mathrm{~min}$. 
EPS isolation and quantification.

EPS was isolated and purified from B. japonicum USDA110 during growth in $\mathrm{PE}$ to $\mathrm{H}_{2} \mathrm{O}_{2}$. The cultures pretreated with various concentrations of $\mathrm{H}_{2} \mathrm{O}_{2}(0,75,150$, and $250 \mu \mathrm{M})$ were grown until the mid $\left(\mathrm{OD}_{600} \approx 0.8\right)$ and late $\left(\mathrm{OD}_{600} \approx 1.5\right)$ exponential phase. EPS was isolated and purified according to the method of Read and Costerton (1987). Total protein content was measured by Bradford's method (Bradford 1976) using a bovine serum albumin as the standard (Bio-Rad, Hercules, CA, U.S.A.) to normalize the total EPS amount. The total carbohydrate content was determined by the phenol-sulfuric acid method, with glucose as the standard (Chang et al. 2007b).

\section{RNA isolation for PE and FS.}

For the PE condition, a 200-ml culture of B. japonicum USDA110 initially supplemented with either $250 \mu \mathrm{M} \mathrm{H} \mathrm{H}_{2}$ or sterilized $\mathrm{ddH}_{2} \mathrm{O}$ was grown under aeration at $30^{\circ} \mathrm{C}$ until the $\mathrm{OD}_{600}$ reached the exponential phase $\left(\mathrm{OD}_{600}\right.$ of 0.8$)$. Then, the cultures were harvested and washed with AG media by centrifugation for $20 \mathrm{~min}$ at $4^{\circ} \mathrm{C}$ and $8,000 \times g$ in a fixed-angle rotor. After decanting the supernatant completely, cell pellets were flash frozen in liquid nitrogen and stored at $-80^{\circ} \mathrm{C}$ until RNA isolation. RNA samples from frozen cells for microarray and qRT-PCR were extracted using a modified hot phenol method as described previously (Bittner et al. 2003). To purify RNA samples, an RNeasy mini kit (Qiagen, Germantown, MD, U.S.A.) was used along with RNase-free DNase (Qiagen) according to the manufacturer's protocol. RNA samples were confirmed on $0.8 \%$ agarose gels prior to use to insure RNA integrity, and quantities were measured by the NanoDrop device (Thermo Scientific, Sugarland, TX, U.S.A.). All extractions of RNA were performed with three independent replications and used for both microarray and qRT-PCR experiments.

For the FS treatment, cultures grown at $30^{\circ} \mathrm{C}$ until the exponential phase $\left(\mathrm{OD}_{600}\right.$ of 0.8$)$ were divided into two cultures and both cultures were immediately treated with either $10 \mathrm{mM}$ $\mathrm{H}_{2} \mathrm{O}_{2}$ or the same volume of sterilized $\mathrm{ddH}_{2} \mathrm{O}$ for $10 \mathrm{~min}$. Cell harvest and RNA isolation were performed as described above.

\section{Microarray experiments and data analysis.}

Whole-genome expression profiles of B. japonicum in response to PE and FS were created using DNA microarray chips that contain 8,453 open reading frames annotated from the genomic sequence of B. japonicum USDA110 (Chang et al. 2007a). Preparation of the microarray, synthesis of cDNA, labeling, hybridization, and scanning were completed as previously described (Chang et al. 2007a). Briefly, after labeling cDNAs with $\mathrm{Cy} 3$ and Cy5 monoreactive dyes (GE Healthcare), the cDNA samples were applied to microarray slides following overnight incubation at $42^{\circ} \mathrm{C}$. Microarray slides were washed and scanned with the Axon GenePix 4200 scanner, and GenePix Pro 6.0 software was used to quantify intensity values. The signal intensities were normalized using the Lowess algorithm and subsequently analyzed by mixed-effect microarray analysis of variance (MAANOVA) (Kerr et al. 2000). Values obtained from the MAANOVA analysis were subjected to significance analysis of microarray (SAM) using the SAM package (Tusher et al. 2001). Because the spots are printed in duplicates on each array, two technical replicates were combined and averaged. Significantly up- and downregulated genes were identified based on a 2.0 -fold cut-off threshold within a false discovery rate lower than $5 \%$ ( $q$ value $\leq 0.05)$. All experiments were performed with three independent replications.

\section{qRT-PCR analysis.}

qRT-PCR was performed to verify the microarray data. qRTPCR methods used in this study were described previously
(Chang et al. 2007a). Briefly, cDNA was synthesized in a 25- $\mu$ l reaction solution containing $1 \mu$ of $\mathrm{M}-\mathrm{MLV}$ reverse transcriptase ( $200 \mathrm{U} / \mu \mathrm{l}$; Promega Corp.), $2 \mu \mathrm{l}$ of random hexamers (250 ng/ $\mu \mathrm{l}$; Invitrogen, Carlsbad, CA, U.S.A.), $1.25 \mu \mathrm{l}$ of 10 $\mathrm{mM}$ dNTPs, and $3 \mu \mathrm{g}$ of total RNA used in the microarray experiment. Of the reaction solution, $1 \mu \mathrm{l}$ of cDNA was used as a template for qRT-PCR. Negative control reactions which lacked reverse transcriptase were used to check for DNA contamination. Gene-specific primers for the selected 21 genes based on expression values and functional categories were designed using Integrated DNA Technologies (Coralville, IA, U.S.A.) company software (Supplementary Table S3). For data normalization, expression values were normalized to the expression of bll0631 (parA) which encodes a chromosomepartitioning protein (Cytryn et al. 2007), a gene constitutively expressed under all experimental conditions examined in this study.

\section{Microarray data accession numbers.}

The raw microarray data are compiled in the National Center for Biotechnology Information Gene Expression Omnibus (GEO) database and are accessible through the GEO series accession numbers GSE26960 and GSE26961 for the PE and FS conditions, respectively.

\section{ACKNOWLEDGMENTS}

This research was supported by a Research Enhancement Program (REP) grant from the University of Texas-Arlington and, in part, by the Basic Science Research Program through the National Research Foundation of Korea (NRF) funded by the Ministry of Education, Science and Technology (2010-0016797) and an Inha University Research grant. We thank R. Jones in the Genomics Core Facility (GCF) at the University of Texas-Arlington for providing technical support for the qRT-PCR analysis and H.-M. Fischer for providing the B. japonicum 9043 strain.

\section{LITERATURE CITED}

Alvarez-Martinez, C. E., Lourenco, R. F., Baldini, R. L., Laub, M. T., and Gomes, S. L. 2007. The ECF sigma factor sigma(T) is involved in osmotic and oxidative stress responses in Caulobacter crescentus. Mol. Microbiol. 66:1240-1255.

Barloy-Hubler, F., Cheron, A., Hellegouarch, A., and Galibert, F. 2004. Smc01944, a secreted peroxidase induced by oxidative stresses in Sinorhizobium meliloti 1021. Microbiology 150:657-664.

Bittner, M., Butow, R., DeRisi, J., Diehn, M., Eberwine, J., Epstein, C. B. Glynne, R., Grimmond, S., Ideker, T., Kacharmina, J. E., Katsabanis, S., Khan, J., Lee, J., Liu, C. L., Marciano, P., Marincola, F. M., McIntosh, T., Monte, D., Pollack, J. R., Rhodius, V., Somerville, S., Tom, E., Wang, E., Wei, J. S., Willhite, D., and Ybarra, S.. 2003. Expression analysis of RNA. Pages 101-288 in: DNA Microarrays: A Molecular Cloning Manual. D. Botwell and J. Sambrook, eds. Cold Spring Harbor Laboratory Press, Cold Spring Harbor, NY, U.S.A.

Bradford, M.M. 1976. A rapid and sensitive method for the quantitation of microgram quantities of protein utilizing the principle of protein-dye binding. Anal Biochem. 72:248-254.

Chang, C., Damiani, I., Puppo, A., and Frendo, P. 2009. Redox changes during the legume-rhizobium symbiosis. Mol. Plant 2:370-377.

Chang, W., Small, D. A., Toghrol, F., and Bentley, W. E. 2006. Global transcriptome analysis of Staphylococcus aureus response to hydrogen peroxide. J. Bacteriol. 188:1648-1659.

Chang, W.-S., Franck, W. L., Cytryn, E., Jeong, S., Joshi, T., Emerich, D. W., Sadowsky, M. J., Xu, D., and Stacey, G. 2007a. An oligonucleotide microarray resource for transcriptional profiling of Bradyrhizobium japonicum. Mol. Plant-Microbe Interact. 20:1298-1307.

Chang, W.-S., van de Mortel, M., Nielsen, L., Nino de Guzman, G., Li, X., and Halverson, L.J. 2007b. Alginate production by Pseudomonas putida creates a hydrated microenvironment and contributes to biofilm architecture and stress tolerance under water-limiting conditions. J. Bacteriol. 189:8290-8299.

Chell, R. M., Sundaram, T. K., and Wilkinson, A. E. 1978. Isolation and characterization of isocitrate lyase from a thermophilic Bacillus sp. Biochem. J. 173:165-177.

Cytryn, E. J., Sangurdekar, D. P., Streeter, J. G., Franck, W. L., Chang, W.- 
S., Stacey, G., Emerich, D. W., Joshi, T., Xu, D., and Sadowsky, M. J. 2007. Transcriptional and physiological responses of Bradyrhizobium japonicum to desiccation-induced stress. J. Bacteriol. 189:6751-6762.

D'Haeze, W., and Holsters, M. 2004. Surface polysaccharides enable bacteria to evade plant immunity. Trends Microbiol. 12:555-561.

D’Haeze, W., Glushka, J., De Rycke, R., Holsters, M., and Carlson, R. W. 2004. Structural characterization of extracellular polysaccharides of Azorhizobium caulinodans and importance for nodule initiation on Sesbania rostrata. Mol. Microbiol. 52:485-500.

Dixon, R., and D. Kahn. 2004. Genetic regulation of biological nitrogen fixation. Nat. Rev. Microbiol. 2:621-631.

Donati, A. J., Jeon, J. M.., Sangurdekar, D., So, J. S., and Chang, W. S. 2011. The genome-wide transcriptional and physiological response of Bradyrhizobium japonicum to paraquat-mediated oxidative stress. Appl. Environ. Microbiol. 77:3633-3643.

Egelhoff, T. T., and Long, S. R. 1985. Rhizobium meliloti nodulation genes-identification of nodDABC gene products, purification of nodA protein, and expression of nodA in Rhizobium meliloti. J. Bacteriol. 164:591-599.

Fischer, H. M., Velasco, L., Delgado, M. J., Bedmar, E. J., Scharen, S., Zingg, D., Gottfert, M., and Hennecke, H. 2001. One of two hemN genes in Bradyrhizobium japonicum is functional during anaerobic growth and in symbiosis. J. Bacteriol. 183:1300-1311.

Fisher, M. A., Plikaytis, B. B., and Shinnick, T. M. 2002. Microarray analysis of the Mycobacterium tuberculosis transcriptional response to the acidic conditions found in phagosomes. J. Bacteriol. 184:40254032 .

Franck, W. L., Chang, W.-S., Qiu, J., Sugawara, M., Sadowsky, M. J., Smith, S. A., and Stacey, G. 2008. Whole-genome transcriptional profiling of Bradyrhizobium japonicum during chemoautotrophic growth. J. Bacteriol. 190:6697-6705.

Garg, N., and Geetanjali. 2009. Symbiotic nitrogen fixation in legume nodules: Process and signaling: A review. Sustain. Agric. 5:519-531.

Gorham, H. C., McGowan, S. J., Robson, P. R., and Hodgson, D. A. 1996. Light-induced carotenogenesis in Myxococcus xanthus: Light-dependent membrane sequestration of ECF sigma factor CarQ by anti-sigma factor CarR. Mol. Microbiol. 19:171-186.

Green, L. S., Karr, D. B., and Emerich, D. W. 1998. Isocitrate dehydrogenase and glyoxylate cycle enzyme activities in Bradyrhizobium japonicum under various growth conditions. Arch. Microbiol. 169:445451

Helmann, J. D. 2002. The extracytoplasmic function (ECF) sigma factors. Adv. Microb. Physiol. 46:47-110.

Iannelli, M. A., Van Breusegem, F., Van Montagu, M., Inze, D., and Massacci, A. 1999. Tolerance to low temperature and paraquat-mediated oxidative stress in two maize genotypes. J. Exp. Bot. 50:523-532.

Kerr, M. K., Martin, M., and Churchill, G. A. 2000. Analysis of variance for gene expression microarray data. J. Comput. Biol. 7:819-837.

Kiraly, Z., ElZahaby, H. M., and Klement, Z. 1997. Role of extracellular polysaccharide (EPS) slime of plant pathogenic bacteria in protecting cells to reactive oxygen species. J. Phytopathol. 145:59-68.

Levine, A., Tenhaken, R., Dixon, R., and Lamb, C. 1994. $\mathrm{H}_{2} \mathrm{O}_{2}$ from the oxidative burst orchestrates the plant hypersensitive disease resistance response. Cell 79:583-593.

Li, S., Xiao, X., Li, J., Luo, J., and Wang, F. 2006. Identification of genes regulated by changing salinity in the deep-sea bacterium Shewanella $\mathrm{sp}$. WP3 using RNA arbitrarily primed PCR. Extremophiles 10:97-104.

Loh, J. T., and Stacey, G. 2001. Feedback regulation of the Bradyrhizobium japonicum nodulation genes. Mol. Microbiol. 41:1357-1364.

Mesa, S., Bedmar, E. J., Chanfon, A., Hennecke, H., and Fischer, H. M. 2003. Bradyrhizobium japonicum NnrR, a denitrification regulator, expands the FixLJ-FixK 2 regulatory cascade. J. Bacteriol. 185:3978-3982.

Mesa, S., Hennecke, H., and Fischer, H. M. 2006. A multitude of CRP/FNR-like transcription proteins in Bradyrhizobium japonicum. Biochem. Soc. Trans. 34:156-159.

Mesa, S., Hauser, F., Friberg, M., Malaguti, E., Fischer, H.-M, and Hennecke, H. 2008. Comprehensive assessment of the regulons controlled by the FixLJ-FixK ${ }_{2}-$ FixK $_{1}$ cascade in Bradyrhizobium japonicum. J. Bacteriol. 190:6568-6579.

Mesa, S., Reutimann, L., Fischer, H. M., and Hennecke, H. 2009. Posttranslational control of transcription factor $\mathrm{FixK}_{2}$, a key regulator for the Bradyrhizobium japonicum-soybean symbiosis. Proc. Natl. Acad. Sci. U.S.A. 106:21860-21865.
Mongkolsuk, S., and Helmann, J. D. 2002. Regulation of inducible peroxide stress responses. Mol. Microbiol. 45:9-15.

Mylona, P., Pawlowski, K., and Bisseling, T. 1995. Symbiotic nitrogenfixation. Plant Cell 7:869-885

Nellen-Anthamatten, D., Rossi, P., Preisig, O., Kullik, I., Babst, M., Fischer, H. M., and Hennecke, H. 1998. Bradyrhizobium japonicum FixK $_{2}$, a crucial distributor in the FixLJ-dependent regulatory cascade for control of genes inducible by low oxygen levels. J. Bacteriol. 180:5251-5255.

Nollen, E. A., and Morimoto, R. I. 2002. Chaperoning signaling pathways: Molecular chaperones as stress-sensing 'heat shock' proteins. J. Cell Sci. 115:2809-2816.

Paget, M. S., Kang, J. G., Roe, J. H., and Buttner, M. J. 1998. sigmaR, an RNA polymerase sigma factor that modulates expression of the thioredoxin system in response to oxidative stress in Streptomyces coelicolor A3(2). EMBO (Eur. Mol. Biol. Organ.) J. 17:5776-5782.

Palma, M., DeLuca, D., Worgall, S., and Quadri, L. E. 2004. Transcriptome analysis of the response of Pseudomonas aeruginosa to hydrogen peroxide. J. Bacteriol. 186:248-252.

Panek, H. R., and O'Brian, M. R. 2004. KatG is the primary detoxifier of hydrogen peroxide produced by aerobic metabolism in Bradyrhizobium japonicum. J. Bacteriol. 186:7874-7880.

Pawlowski, K., and Bisseling, T. 1996. Rhizobial and actinorhizal symbioses: What are the shared features? Plant Cell 8:1899-1913.

Read, R. R., and Costerton, J. W. 1987. Purification and characterization of adhesive exopolysaccharides from Pseudomonas putida and Pseudomonas fluorescens. Can. J. Microbiol. 33:1080-1090.

Rubio, M. C., James, E. K., Clemente, M. R., Bucciarelli, B., Fedorova, M., Vance, C. P., and Becana, M. 2004. Localization of superoxide dismutases and hydrogen peroxide in legume root nodules. Mol. Plant-Microbe. Interact. 17:1294-1305.

Sadowsky, M. J., Tully, R. E., Cregan, P. B., and Keyser, H. H. 1987. Genetic diversity in Bradyrhizobium japonicum serogroup 123 and its relation to genotype-specific nodulation of soybean. Appl. Environ. Microbiol. 53:2624-2630.

Salunkhe, P., Topfer, T., Buer, J., and Tummler, B. 2005. Genome-wide transcriptional profiling of the steady-state response of Pseudomonas aeruginosa to hydrogen peroxide. J. Bacteriol. 187:2565-2572.

Santos, R., Herouart, D., Sigaud, S., Touati, D., and Puppo, A. 2001. Oxidative burst in alfalfa-Sinorhizobium meliloti symbiotic interaction. Mol. Plant-Microbe. Interact. 14:86-89.

Scandalios, J. G. 1993. Oxygen stress and superoxide dismutases. Plant Physiol. 101:7-12.

Soto, M. J., Sanjuan, J., and Olivares, J. 2006. Rhizobia and plant-pathogenic bacteria: Common infection weapons. Microbiology 152:31673174

Storz, G., Tartaglia, L. A., Farr, S. B., and Ames, B. N. 1990. Bacterial defenses against oxidative stress. Trends Genet. 6:363-368.

Tao, H., Bausch, C., Richmond, C., Blattner, F. R., and Conway, T. 1999 Functional genomics: Expression analysis of Escherichia coli growing on minimal and rich media. J. Bacteriol. 181:6425-6440.

Tusher, V. G., Tibshirani, R., and Chu, G. 2001. Significance analysis of microarrays applied to the ionizing radiation response. Proc. Natl Acad. Sci. U.S.A. 98:5116-5121.

van Rhijn, P., Goldberg, R. B., and Hirsch, A. M. 1998. Lotus corniculatus nodulation specificity is changed by the presence of a soybean lectin gene. Plant Cell 10:1233-1250.

Watanabe, S., Yamaoka, N., Takada, Y., and Fukunaga, N. 2002. The coldinducible icl gene encoding thermolabile isocitrate lyase of a psychrophilic bacterium, Colwellia maris. Microbiology 148:2579-2589.

Zhang, X., Liu, S., and Takano, T. 2008. Overexpression of a mitochondrial ATP synthase small subunit gene (AtMtATPO) confers tolerance to several abiotic stresses in Saccharomyces cerevisiae and Arabidopsis thaliana. Biotechnol. Lett. 30:1289-1294.

\section{AUTHOR RECOMMENDED INTERNET RESOURCES}

The Jackson Laboratory, Churchill Group website: www.jax.org/staff/churchill

National Center for Biotechnology Information Gene Expression Omnibus (GEO) database: www.ncbi.nlm.nih.gov/geo

RhizoBase website: genome.kazusa.or.jp/rhizobase 